\title{
Antimicrobial resistance of three common molecularly identified pathogenic bacteria to Allium aqueous extracts
}

\author{
Héctor D. Arzate Serrano ${ }^{a}$, María A. Mariezcurrena-Berasain ${ }^{\mathrm{a}, *}$, \\ Adriana Del Carmen Gutiérrez Castillo ${ }^{a}$, Benjamín Valladares Carranza ${ }^{a}$, \\ Alberto Barbabosa Pliego ${ }^{\mathrm{a}}$, Martín Talavera Rojas ${ }^{\mathrm{a}}$, Uchenna Y. Anele ${ }^{\mathrm{b}}$, Abdelfattah Z.M. Salem ${ }^{\mathrm{a}}$, \\ Raymundo R. Rivas-Caceres ${ }^{\mathrm{c}, * *}$
}

${ }^{a}$ Universidad Autónoma del Estado de México, Facultad de Medicina Veterinaria y Zootecnia, Toluca, México, C.P. 50090, Mexico

${ }^{\mathrm{b}}$ North Carolina Agricultural and Technical State University, Greensboro, NC, 27411, USA

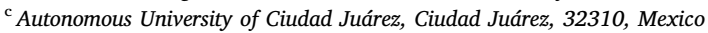

\section{A R T I C L E I N F O}

\section{Keywords:}

Allium sativum

Extracts

Inhibition

Bacterial resistance

Antimicrobial

\begin{abstract}
A B S T R A C T
The aim of this work was to evaluate the in vitro bacterial inhibition of different types of garlic on Escherichia coli ATCC 25922, Listeria monocytogenes and Staphylococcus aureus. The bacterial strains were molecularly identified using gen 16S rDNA molecular identification. Four different types of garlics were used: 1) white, 2) Japanese, 3) elephant and 3) black, and these were evaluated at two different concentrations ( 0.25 and $0.125 \mathrm{~g} / \mathrm{mL})$ per garlic type. Bioactive compounds present in the garlics were identified using high-performance liquid chromatography coupled to ultraviolet detector (HPLC-UV), and total polyphenols were quantified by the Folin-Ciocalteu technique. The Kirby-Bauber method was used for the bacterial evaluation. Aqueous extract of black garlic had the highest amount of polyphenols $6.26 \pm 0.21 \mathrm{mg} \mathrm{GAE} / \mathrm{mL}$. The area of inhibition was measured and classified as sensitive, intermediate or resistant. Using the disc diffusion assay, higher concentration $(0.25 \mathrm{~g} / \mathrm{mL})$ of aqueous extract of white garlic had the highest antibacterial activity area, with $21.46 \pm 3.94 \mathrm{~mm}$ for L. monocytogenes, $20.61 \pm 2.47 \mathrm{~mm}$ for $S$. aureus and $17.83 \pm 2.21 \mathrm{~mm}$ for $E$. coli. White garlic had comparable antimicrobial activity as the control (tetracycline at $30 \mu \mathrm{g}$ ) as indicated by the size of the inhibition halos. Based on your results, white garlic can be used as an alternative to synthetic antimicrobials.
\end{abstract}

\section{Introduction}

Previously, natural products were used to combat diseases, however, with the discovery of synthetic antibiotics, they were gradually replaced $[1,52,53]$. Natural products used to be the major ingredient of many drugs but pharmaceutical companies have decreased or even eliminated research on natural products [2,42-46,52]. The focus has been on synthetic antibiotics and their indiscriminate use have reduced their effectiveness against infectious diseases in addition to incidences of antibiotics resistance [3,47-50]. Foodborne diseases are still a public health problem worldwide and the causal agents are mainly Escherichia coli O157: H7, Salmonella spp., Listeria monocytogenes, and Clostridium botulinum $[4,5]$. Bacteria have the ability to adapt to an environment and develop resistance mechanisms, which can be of natural or acquired origin $[6,7,51]$.
Due to the current problems of antibiotics resistance facing the livestock industry, natural products can be viable and economical alternatives $[55,57,63]$. One of such natural products is garlic (Allium sativum) and there is documented literature on its antibacterial effect $[8,9]$. Therefore, there is a need to look for new medicines of herbal origin as they cannot contribute to antibiotics resistance and they have little or no toxic effect on livestock [10,57,64]. Garlic (Allium sativum) is an antimicrobial characterized by its high content of sulfuric compounds $[11,12,54]$ and previous studies reported that garlic has a broad spectrum of antibacterial activity against E. coli, Salmonella spp. [9,13]. Kamra et al. [14] reported garlic as anti-methanogenic and anti-protozoal agent with the ability to reduce methane emission. They concluded that garlic and plant extract, in general, can be used as an ecofriendly rumen modifier for sustainable production [15,56-62]. During processing, the unstable compounds of fresh garlic, including alliin,

\footnotetext{
* Corresponding author.

** Corresponding author.

E-mail addresses: maria.mareizcurrena@yahoo.com.mx (M.A. Mariezcurrena-Berasain), rriivas@uacj.mx (R.R. Rivas-Caceres).
} 
become stable compounds that include s-allylcysteine (SAC), the watersoluble compound with potent antioxidant effect [16]. The study of medicinal plants is still a work in progress but it has the potential to address some of the major issues such as the antibiotics resistance that have plagued the livestock industry. In the present study, we evaluated two concentrations $(0.25$ and $0.125 \mathrm{~g} / \mathrm{mL})$ of aqueous extracts of white, Japanese, elephant and black garlic for their antibacterial activities on E. coli, L. monocytogenes and Staphylococcus aeurus.

\section{Materials and methods}

\subsection{Preparation of the extracts}

The study was carried out in the Laboratory of Bacteriology, the Center for Research and Advanced Studies in Animal Health of the Autonomous University of the State of Mexico. Four varieties of garlic were used: white, Japanese, elephant and black, and these were obtained from a local market, (Juarez, Toluca State State of Mexico). For the preparation of the aqueous extracts, $50 \mathrm{~g}$ of each garlic per $200 \mathrm{~mL}$ of distilled water $(0.25 \mathrm{~g} / \mathrm{mL})$ and $50 \mathrm{~g}$ of garlic per $400 \mathrm{~mL}$ of water $(0.125 \mathrm{~g} / \mathrm{mL})$ were used for the second concentration. The garlic was ground with a commercial laboratory blender and liquefied with water for $5 \mathrm{~min}$. The resulting solutions were filtered twice with Watman ${ }^{\circledR}$ No. 1 paper, and the extracts were stored under refrigeration $\left(4^{\circ} \mathrm{C}\right)$ until needed.

\subsection{Extract characterization and biological properties of active molecules}

Aqueous extract was analyzed for its chemical compounds using GC/MS apparatus and the conditions of column oven and temperature program have been previously described in Refs. $[17,18]$. The identification of chemical compounds was done by matching their retention times and mass spectra with those reported in WILEY 09 [19] and NIST 11 Mass Spectral databases (Table 1).

For the quantification of allicin (by oxidation of diallyl disulfide with hydrogen peroxide), the methodology reported by Ref. [20] was followed, using high performance liquid chromatography coupled to ultraviolet detector (HPLC-UV), a ODS C18 reverse phase column (254 $\mathrm{mm} \times 0.46 \mathrm{~mm}$ ID, $5 \mu \mathrm{m}$ ). The analysis conditions were mobile phase Methanol/Water $45 / 55$ at a flow rate of $0.8 \mathrm{~mL} / \mathrm{min}$; Analysis temperature $25{ }^{\circ} \mathrm{C}$ and UV detection at $230 \mathrm{~nm}$ [21] (Table 2).

\subsection{Total polyphenols}

Quantification of total polyphenols was performed using the FolinCiocalteu technique [22]. A standard curve was made with gallic acid and the absorbance was measured at $760 \mathrm{~nm}$. The $\mathrm{pH}$ of the extracts was measured with a potentiometer (Conductronic, PC18, Puebla, Mexico).

\subsection{Origin and molecular identification of bacterial strains}

For comparison of the diameter of the inhibition halo, the bacterial strains used were: E. coli (ATCC ${ }^{\circledR} 25922^{\mathrm{TM}}$ ), L. monocytogenes (field

Table 1

Chemical constituents of aqueous extract.

\begin{tabular}{lll}
\hline Peak & Compound name & Area(\%) \\
\hline 1. & 2-Ethylidene [1,3]dithiane & 0.39 \\
2. & 3-Vinyl-1,2-dithiacyclohex-4-ene & 12.62 \\
3. & 3-Vinyl-1,2-dithiacyclohex-5-ene & 21.47 \\
4. & Diallyl disulfide & 3.16 \\
5. & Dimethyl trisulfide & 1.23 \\
6. & Methyl 2-propanol trisulfide & 2.49 \\
7. & Di-2-propenyl trisulfide & 5.90
\end{tabular}

Table 2

Allicin content of aqueous extracts.

\begin{tabular}{ll}
\hline Type of extract & Allicin content (ppm) \\
\hline AEWG & $2,00 \pm 0,007$ \\
AEJG & $0,02 \pm 0,003$ \\
AEEG & $0,01 \pm 0,002$ \\
AEBG & $0 \pm 0$ \\
\hline
\end{tabular}

AEWG, Aqueous extract of white garlic; AEJG, Aqueous Japanese garlic extract; AEEG, Aqueous extract of elephant garlic; AEBG, Aqueous extract of black garlic; ppm, Parts per million.

isolate obtained from ovine brain and in a selective medium, Listeria Enrichment Broth, Sigma-Aldrich, Inc.) as described by Ref. [23] and $S$. aureus (isolated from a lesion located on the back of a canine; Table 3).

However, $S$. aureus is a member of the microbiota of human, but it is common to isolate it from skin and mucous membranes of canine species [24]. S. aureus, is in the group of multiresistant bacteria so they are a challenge for the veterinary profession, since they can cause morbidity and mortality in pets, in addition to being a zoonotic risk [25].

Isolation of $L$. monocytogenes in food creates the need to seek alternatives to prevent the proliferation of this bacterium. In many foods, this is done through the use of chemical preservatives, which has been questioned due to its potentially toxic and carcinogenic effects. These shortcomings have resulted in the push for the use of natural food additives, promoting the exploration of natural antimicrobial compounds as an alternative [26].

The bacterial strains were identified by gen 16S rDNA molecular identification; protocol was developed according to Kavitha et al. [27]. The extracted genomic DNA was subjected to 16S rDNA sequence analysis. The resulting sequences were aligned and analyzed with homologous sequences from other bacteria.

\subsection{Experimental design}

A completely randomized design with a $4 \times 2 \times 3$ factorial arrangement was used with ten replications for each bacterium. Independent variables were aqueous extracts; white garlic (AEWG), Japanese (AEJG), elephant (AEEG) and black (AEBG), concentrations $(0.25$ and $0.125 \mathrm{~g} / \mathrm{mL})$ and bacteria (E. coli ATCC 25922, L. monocytogenes and $S$. aureus) and the response/dependent variable was the inhibition of bacterial growth. An analysis of variance and comparison of means was performed by the Tukey Test $(\mathrm{P} \geq 0.05)$ using the statistical package Statgraphics Plus version 5.0.

\subsection{Inhibition capacity}

For this test, the Kirby-Bauber method was used and the extracts' ability to inhibit bacterial growth was determined by plaque diffusion. To determine the appropriate control to used, a preliminary test was carried out in which the bacteria were challenged with 7 different antimicrobials (Polydisks for Gram-negative and Gram-positive bacteria, Productos Biológicos de México, S.A.). With the help of a vernier rule, the area of bacterial inhibition around the senses were measured and classified as sensitive (S), intermediate (I) or resistant (R) according to Wayne USA: CLSI (Clinical and Laboratory Standards Institute 2012).

\section{Results}

Concentrations of total polyphenols in the extracts are shown in Fig. 1. Higher concentration $(0.25 \mathrm{~g} / \mathrm{mL})$ of aqueous extract of black garlic (AEBG) had the highest total polyphenols $(6.26 \mu \mathrm{g}$ gallic acid equivalents $(\mathrm{GAE} / \mathrm{mL})$ and $\mathrm{pH}$ of $4.61 \pm 0.03$; the lowest values were noted for aqueous extract of elephant garlic (AEEG) $0.26 \mu \mathrm{g} \mathrm{GAE} / \mathrm{mL}$ and $\mathrm{pH}$ of $6.61 \pm 0.01$. 
Table 3

Origin of bacterial strains used during the evaluation.

\begin{tabular}{|c|c|c|c|}
\hline Origin & Anatomical site description of the lesion & Biochemical & Bacterial species \\
\hline $\begin{array}{l}\text { Creole canine } \\
\quad \text { Male } \\
5 \text { years }\end{array}$ & $\begin{array}{l}\text { Presence of dermatitis of wet appearance, in the area of the chin, left flank of the } \\
\text { thigh and rump } \\
\text { Presence of boils, ulcers and superficial scabs } \\
\text { Pyoderma in the left groin } \\
\text { No treatment } \\
\text { Two weeks with the problem }\end{array}$ & $\begin{array}{l}\text { Gram staining: Cluster Grammar Coconut } \\
\text { Coagulase: Positive } \\
\text { Blood agar hemolysis: Positive } \beta \\
\text { Catalase: Negative } \\
\text { Oxidase: Negative } \\
\text { L-Arabinose: negative } \\
\text { Sucrose: Positive } \\
\text { Maltose: Positive } \\
\text { D-Ribosa: Positive } \\
\text { Hyaluronidase: Positive } \\
\text { Nitrate reduction: positive } \\
\text { DNase: Positive } \\
\text { O/F: F }\end{array}$ & Staphylococcus aureus \\
\hline $\begin{array}{l}\text { Suffolk sheep } \\
\text { Male } \\
2 \text { years }\end{array}$ & $\begin{array}{l}\text { Incoordination, sudden death. } \\
\text { Sample: Cerebellum/medulla oblong } \\
\text { Sample: silo }\end{array}$ & $\begin{array}{l}\text { Gram staining: Gram positive bacillus } \\
\text { Growth in BD PALCAM Listeria Agar }{ }^{\oplus} \text { : Positive } \\
\text { Catalase: Positive } \\
\text { Oxidase: Negative } \\
\text { Motility test: } \\
4{ }^{\circ} \mathrm{C} \text { Negative } \\
37^{\circ} \mathrm{C} \text { Positive (surface) } \\
\text { Mannitol: Negative } \\
\text { Rhamnose: Positive } \\
\text { Xilosa: Negative } \\
\text { Indole: Negative } \\
\text { Urea: Negative } \\
\text { Methyl Red: Positive } \\
\text { Voges-Proskauer: Positive Nitrate Reduction: } \\
\text { Negative }\end{array}$ & Listeria monocytogenes \\
\hline
\end{tabular}

For E. coli, higher concentration $(0.25 \mathrm{~g} / \mathrm{mL})$ of white garlic (AEWG) had the highest inhibition with $17.83 \mathrm{~mm}$ compared with aqueous extract of Japanese garlic (AEJG) and AEEG with 9.80 and $2.93 \mathrm{~mm}$, respectively. Similar trend was noted for the lower the concentration $(0.125 \mathrm{~g} / \mathrm{mL})$ of the extracts, with the highest inhibition halo noted for AEWG with $13.11 \mathrm{~mm}$. No halo was noted for AEBG. In the case of $S$. aureus, AEWG had 20.61- and 17.87-mm halos for the higher and lower concentrations, respectively. The zone of inhibition for AEJG and AEEG were smaller with values of 8.12 and $0.82 \mathrm{~mm}$ and 9.01 and $3.13 \mathrm{~mm}$, respectively. Higher concentration of white garlic had the biggest zone of inhibition $(21.46 \mathrm{~mm})$ on $L$. monocytogenes, followed by Japanese garlic with $5.88 \mathrm{~mm}$ and elephant garlic with $4.32 \mathrm{~mm}$. As noted in the other two bacterial, AEBG showed no antibacterial activity in both concentrations.
The inhibition zones of the seven commercial antimicrobials used in the preliminary study are shown in Table 4 . Based on the result, Tetracycline $(30 \mu \mathrm{g})$ was selected as a positive control and nitrofurantoin $(300 \mu \mathrm{g})$ as a negative control in the present study. The zone of inhibition on bacterial growth by the different garlic treatments is shown in Table 5. With the exception of AEWG, no halo was noted for the other treatments.

\section{Discussion}

The analysis identified 2-ethylidene[1,3]dithiane, 3-Vinyl-1,2-dithiacyclohex-5-ene, 3-Vinyl-1,2-dithiacyclohex-4-ene, diallyl disulfide, dimethyl trisulfide and methyl 2-propanol trisulfide. Allicin represents $70-80 \%$ of the thiosulphinates formed and previous reports

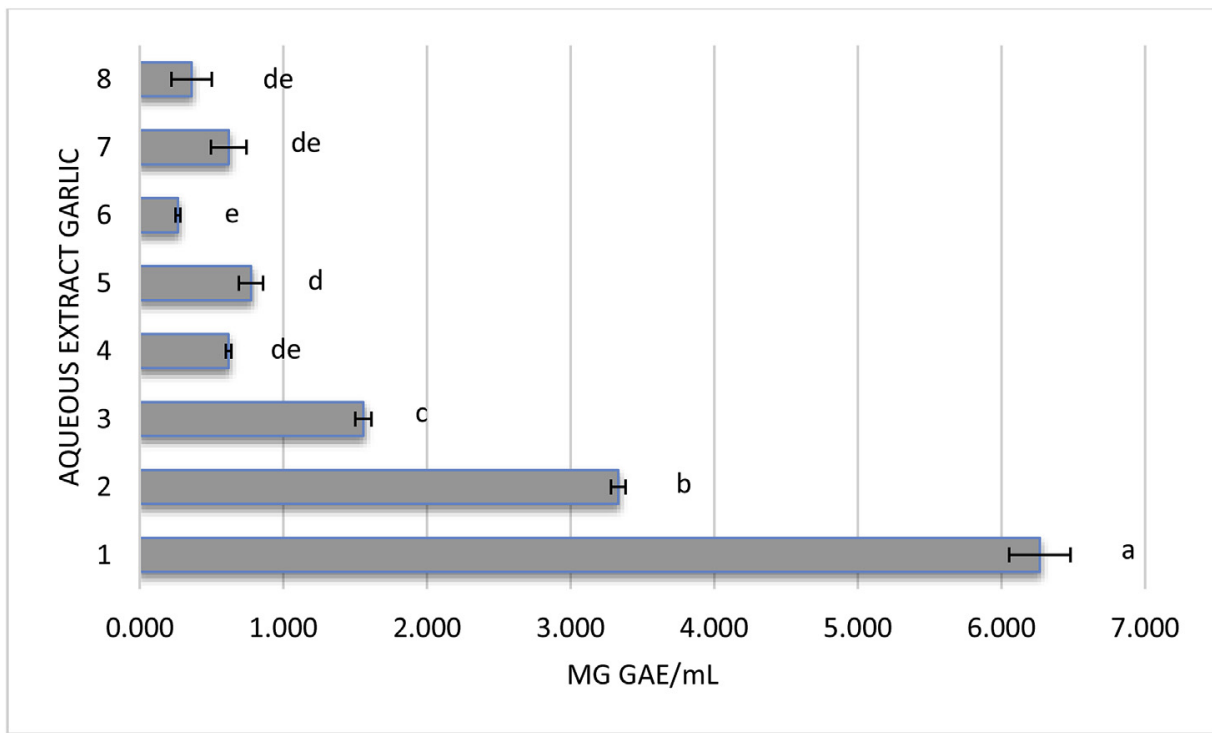

Fig. 1. Content of total polyphenols (expressed in $\mu \mathrm{g}$ equivalents to gallic acid) of the aqueous extracts of garlic.

1 , Aqueous extract of black garlic (AEBG) at $0.25 \mathrm{~g} / \mathrm{mL} \mathrm{2,} \mathrm{AEBG} \mathrm{at} 0.125 \mathrm{~g} / \mathrm{mL} ; 3$, Aqueous extract of white garlic (AEWG) at $0.25 \mathrm{~g} / \mathrm{mL} ; 4$, AEWG at $0.125 \mathrm{~g} / \mathrm{mL} ; 5$, Aqueous extract of elephant garlic (AEEG) at $0.25 \mathrm{~g} / \mathrm{mL} ; 6$, AEEG at $0.125 \mathrm{~g} / \mathrm{mL}$; 7, Aqueous extract of Japanese garlic (AEJG) at $0.25 \mathrm{~g} / \mathrm{mL} ; 8, \mathrm{AEJG}$ at $0.125 \mathrm{~g} / \mathrm{mL}$. 
Table 4

Inhibition halos (mm) in vitro for commercial antimicrobials and their classification according to the CLSI (Clinical and Laboratory Standards Institute).

\begin{tabular}{|c|c|c|c|c|c|c|c|c|c|}
\hline Bacteria & $\begin{array}{l}\text { CF } \\
30 \mu g\end{array}$ & $\begin{array}{l}\text { CIP } \\
5 \mu \mathrm{g}\end{array}$ & $\begin{array}{l}\text { FO } \\
50 \mu \mathrm{g}\end{array}$ & $\begin{array}{l}\text { GM } \\
10 \mu g\end{array}$ & $\begin{array}{l}\text { MAC } \\
300 \mu \mathrm{g}\end{array}$ & $\begin{array}{l}\mathrm{TE} \\
30 \mu \mathrm{g}\end{array}$ & $\begin{array}{l}\text { TSX } \\
25 \mu g\end{array}$ & SEM & $P$ value \\
\hline E. coli ATCC 25922 & $14.95 \pm 0.86^{c}$ & $21.39 \pm 2.36^{\mathrm{b}}$ & $18.20 \pm 1.32^{\mathrm{bc}}$ & $19.87 \pm 0.94^{\mathrm{b}}$ & $0^{d}$ & $26.68 \pm 0.84^{\mathrm{a}}$ & $25.46 \pm 1.25^{\mathrm{a}}$ & 1.86 & 0.001 \\
\hline CLSI & $\mathrm{I}$ & S & $S$ & $\mathrm{~S}$ & $\mathrm{R}$ & S & $S$ & & \\
\hline S. aureus & $24.58 \pm 1.42^{\mathrm{a}}$ & $19.36 \pm 1.36^{\mathrm{b}}$ & $0^{\mathrm{d}}$ & $12.11 \pm 2.13^{c}$ & $0^{\mathrm{d}}$ & $28.12 \pm 1.30^{\mathrm{a}}$ & $26.03 \pm 1.22^{\mathrm{a}}$ & 2.48 & 0.001 \\
\hline CLSI & $\mathrm{S}$ & I & $\mathrm{R}$ & $\mathrm{R}$ & $\mathrm{R}$ & S & S & & \\
\hline L. monocytogenes & $24.26 \pm 1.11^{\mathrm{a}}$ & $21.14 \pm 1.89^{\mathrm{b}}$ & $25.66 \pm 0.84^{\mathrm{a}}$ & $19.34 \pm 0.72^{\mathrm{b}}$ & $0^{c}$ & $25.39 \pm 1.03^{\mathrm{a}}$ & $24.47 \pm 1.21^{\mathrm{a}}$ & 1.90 & 0.001 \\
\hline CLSI & $S$ & S & S & $\mathrm{S}$ & $\mathrm{R}$ & S & S & & \\
\hline
\end{tabular}

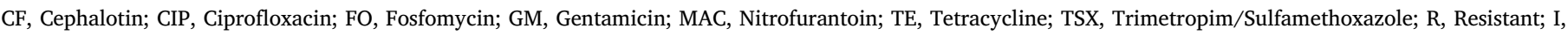

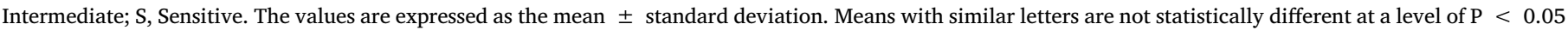
according to the Tukey test.

documented the presence of allicin in garlic extracts [28,29]. They mentioned that allicin is converted into vinyl dithiins and into other compounds such as methyl 2-propanol disulphide, Dimethyl trisulphide and Diallyl tetrasulphide. Wang et al. [30] concluded that these compounds are the main sulfur components of fresh garlic which decompose and form other compounds. The black garlic is SAC [31] (Table 1).

Contrary to expectation, greater concentration of total polyphenols in black garlic did not have any effect on the bacteria. The antibacterial property of garlic is attributed to allicin, which is produced by grounding garlic. Allicin inhibits sulfhydryl enzymes and has been reported to reduce inflammation [8]. Cáceres et al. [32] highlighted the importance of the synergy between phenolic and sulfur compounds by blocking the activity of reactive oxygen on proteins, lipids and DNA. Another mechanism of action is the inhibition of RNA, DNA and protein synthesis [33].

Results showed that only the higher concentration of white garlic was comparable to the control treatment (tetracycline) in inhibiting $S$. aureus and L. monocytogenes. [34], reported a linear relation between garlic concentration and the diameter of inhibition halos, which they attributed to the effect of allicin and other sulfur compounds. García Rico et al. [35] evaluated the antibacterial activity of aqueous extract of three species of the Allium family (Allium sativum, Allium fistulosum and Allium cepa) on five bacterial strains, concluding that $A$. cepa showed greater effectiveness against $E$. coli with inhibition halos of $15 \mathrm{~mm}$ in diameter. Similarly, Salazar Córdova [36] reported a zone of inhibition of $14.3 \mathrm{~mm}$ against $E$. coli, with $25 \%$ concentration of aqueous extract of A. sativum. A previous study by Jiménez [2] reported that a range of 15.5-24.5 mm inhibition zones were established against $E$. coli 25922 , S. aureus Methicillin Resistant and S. aureus ATCC 25923 using a garlic concentration of $250 \mathrm{mg} / \mathrm{mL}$.

The allicin precursor enzyme, allinase, is inactivated by heat, so that the desirable bioactive is not formed if it is heated before cell disruption
[37]. This agrees with Pérez [38], who reported that during cooking, sulfur losses occur due to high temperature; and this could be the reason why black garlic extract showed no antibacterial activity. This reaction could either be enzymatic degradation or Maillard reaction responsible for changes in taste, smell and color [39,40]. Ryu and Kang [41] reported that this process increases the concentration of flavonoids, pyruvate, total phenol, SAC, free sugars and minerals.

In conclusion, higher concentration $(0.25 \mathrm{~g} / \mathrm{mL})$ of aqueous extract of white garlic had the best antibacterial activity against Escherichia coli ATCC 25922, Listeria monocytogenes and Staphylococcus aeurus compared with the aqueous extracts of Japanese garlic and elephant garlic. Aqueous extract of black garlic had no antimicrobial action on the bacteria studied. According to the results from the present study, the antimicrobial action of the aqueous extract of white garlic was comparable to tetracycline and can be used to replace synthetic antimicrobials.

\section{Acknowledgment}

The results are part of the project "Evaluation of garlic extract on productive, immunological parameters and the quality of rabbit meat" $4117 / 2016$ UAEM - and are part of doctoral thesis of Héctor Daniel Arzate Serrano, UAEMéx and CONACYT.

\section{CRediT authorship contribution statement}

Héctor D. Arzate Serrano: Conceptualization, Data curation, Formal analysis, Investigation, Methodology, Writing - original draft. María A. Mariezcurrena-Berasain: Funding acquisition, Supervision, Project administration. Adriana Del Carmen Gutiérrez Castillo: Writing - review \& editing. Benjamín Valladares Carranza: Writing review \& editing. Alberto Barbabosa Pliego: Writing - review \& editing. Martín Talavera Rojas: Writing - review \& editing. Uchenna

Table 5

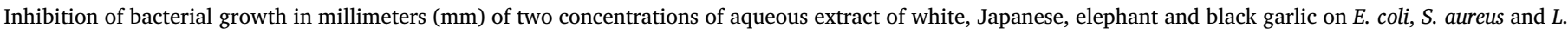
monocytogenes.

\begin{tabular}{|c|c|c|c|c|c|c|c|c|}
\hline \multirow[t]{2}{*}{ Bacteria } & \multicolumn{4}{|l|}{$0,25 \mathrm{~g} / \mathrm{mL}$} & \multirow{2}{*}{$\begin{array}{l}\mathrm{TE} \\
-30 \mu \mathrm{g}\end{array}$} & \multirow{2}{*}{$\begin{array}{l}\text { MAC } \\
300 \mu \mathrm{g}\end{array}$} & \multirow[t]{2}{*}{ SEM } & \multirow[t]{2}{*}{$P$ value } \\
\hline & AEWG & AEJG & AEEG & AEBG & & & & \\
\hline E. coli ATCC 25922 & $17.83 \pm 1.49^{\mathrm{a}}$ & $9.65 \pm 1,59^{\mathrm{b}}$ & $0^{c}$ & $0^{c}$ & $26.24 \pm 0.84$ & 0 & 1.20 & 0.001 \\
\hline S. aureus & $20.78 \pm 1.53^{\mathrm{a}}$ & $9.78 \pm 2,23^{\mathrm{c}}$ & $13.28 \pm 1.52^{\mathrm{b}}$ & $0^{\mathrm{d}}$ & $24.64 \pm 1.05$ & 0 & 1.46 & 0.001 \\
\hline L. monocytogenes & $21.57 \pm 3.25^{\mathrm{a}}$ & $11.79 \pm 0,56^{\mathrm{b}}$ & $12.48 \pm 1.16^{\mathrm{b}}$ & $0^{c}$ & $25.52 \pm 0.61$ & 0 & 1.68 & 0.001 \\
\hline \multirow[t]{2}{*}{ Bacteria } & $0,125 \mathrm{~g} / \mathrm{mL}$ & & & & $\mathrm{TE}$ & MAC & SEM & $P$ value \\
\hline & AEWG & AEJG & AEEG & AEBG & $30 \mu g$ & $300 \mu \mathrm{g}$ & & \\
\hline E. coli ATCC 25922 & $13.10 \pm 1.28^{\mathrm{a}}$ & $0^{\mathrm{b}}$ & $0^{\mathrm{b}}$ & $0^{\mathrm{b}}$ & $26.24 \pm 0.84$ & 0 & 0.91 & 0.001 \\
\hline S. aureus & $18.06 \pm 1.60^{\mathrm{a}}$ & $0^{\mathrm{b}}$ & $0^{\mathrm{b}}$ & $0^{\mathrm{b}}$ & $24.64 \pm 1.05$ & 0 & 1.41 & 0.001 \\
\hline L. monocytogenes & $16.48 \pm 2.52^{\mathrm{a}}$ & $0^{\mathrm{b}}$ & $0^{\mathrm{b}}$ & $0^{\mathrm{b}}$ & $25.52 \pm 0.61$ & 0 & 1.15 & 0.001 \\
\hline
\end{tabular}

AEWG, Aqueous extract of white garlic; AEJG, Aqueous Japanese garlic extract; AEEG, Aqueous extract of elephant garlic; AEBG, Aqueous extract of black garlic; TE, Tetracycline; MAC, Nitrofurantoin. The values are expressed as the mean \pm standard deviation. Means with similar letters are not statistically different at a level of $\mathrm{P}<0.05$ according to the Tukey test. 
Y. Anele: Writing - review \& editing. Abdelfattah Z.M. Salem: Writing - review \& editing. Raymundo R. Rivas-Caceres: Validation, Visualization.

\section{Declaration of competing interest}

The authors declare no conflict of interest.

\section{References}

[1] E.N.R. Sauceda, Use of natural antimicrobial agents in the conservation of fruits and vegetables Ra Ximhai, Sci. J. Soc. Cult. Sustain. Dev. 7 (2011) 153-170.

[2] Jiménez, Y., Sebastián, C. , Evaluation of the Antibiotic Effect of the Aqueous Extracts of Allium Sativum (Garlic) and of Coriandrum Sativum (Culantro) by the Diffusion Sensitivity Method on Bauer-Kirby Agar, on Bacterial Strains of Staphylococcus aureus, Escherichia coli, Salmonella enterica Serovar Typhi and Salmonella Enteric Serovar Choleraesuis; in Comparison with the Antibiotics Gentamicin and Ampicillin 2015, Catholic University of Ecuador.

[3] C.L. Ventola, The antibiotic resistance crisis: part 1: causes and threats, P T: A Peer Rev. J. Formul. Manag. 40 (4) (2015) 277-283.

[4] C. Barton Behravesh, T.F. Jones, D.J. Vugia, C. Long, R. Marcus, K. Smith, S. Thomas, S. Zansky, K.E. Fullerton, O.L. Henao, E. Scallan, Deaths associated with bacterial pathogens transmitted commonly through food: foodborne diseases active surveillance network (FoodNet), 1996-2005, J. Infect. Dis. 204 (2) (2011) 263-267.

[5] WHO World Health Organization, Guidelines on Use of Medically Important Antimicrobials in Food-Producing Animals, (2017).

[6] R. Cantón, M.I. Morosini, Emergence and spread of antibiotic resistance following exposure to antibiotics, FEMS Microbiol. Rev. 35 (2011) 977-991.

[7] N.H. Mansoub, M.A.M. Nezhady, Effect of garlic, thyme and yogurt compared to antibiotics on performance, immunity and some blood parameters of broiler chickens, Indian J. Anim. Sci. 81 (2011) 1197-1200.

[8] L. Bayan, P.H. Koulivand, A. Gorji, Garlic: a review of potential therapeutic effects, Avicenna J. Phytomed. 4 (1) (2014) 1-14.

[9] G. Gebreyohanne, M. Gebreyohanne, Medicinal values of garlic: a review, Int. J. Med. Med. Sci. 5 (2013) 401-408.

[10] J.R. Ruiz, M. Roque, Antimicrobial activity of four plants from the north-east of Peru, Sci. Res. 12 (2009) 41-47.

[11] J. Singh, M. Sharma, N. Singh, P. Kaur, A.P.S. Sethi, S.S. Sikka, Effect of sun-dried whole bulb garlic powder on nutrient utilization, blood parameters, duodenum morphology and faecal microbial load in broiler chickens, Indian J. Anim. Sci. 87 (2017) 195-198.

[12] T. López, Garlic pharmacological properties and therapeutic indications, Phytother. Pharmaceut. Field 26 (2007) 78-81.

[13] D. Deresse, Antibacterial effect of garlic (Allium sativum) on Staphylococcus aureus: an in vitro study, Asian J. Med. Sci. 2 (2010) 62-65.

[14] D.N. Kamra, et al., Garlic as a rumen modifier for eco-friendly and economic livestock production, J. Appl. Anim. Res. 40 (2) (2012) 90-96.

[15] G.E. Boyhan, W.T. Kelley, D.M. Granberry, Production and Management of Garlic, Elephant Garlic and Leek, Extension Horticulturists Cooperative Extension Service, 2009.

[16] M. Corzo-Martínez, N. Corzo, M. Villamiel, Biological properties of onions and garlic, Trends Food Sci. Technol. 18 (12) (2007) 609-625.

[17] A.Z.M. Salem, M.Z.M. Salem, M.M. El-Adawy, P.H. Robinson, Nutritive evaluations of some browse tree foliages during the dry season: secondary compounds, feed intake and in vivo digestibility in sheep and goats, Anim. Feed Sci. Technol. 127 (3-4) (2006) 251-267.

[18] A.Z.M. Salem, A.C. Ryena, M.M.Y. Elghandour, L.M. Camacho, A.E. Kholif, M.C. Salazar, I.A. Domínguez, R.M. Jiménez, E.M. Almaraz, A.G.L. Martínez M.A. Mariezcurrena, Influence of Salix babylonica extract in combination or not with increasing levels of minerals mixture on in vitro rumen gas production kinetics of a total mixed ration, Ital. J. Anim. Sci. 13 (4) (2014) 3110.

[19] W. Oberacher, S.D. Weinmann, Quality evaluation of tandemmass spectral libraries, Anal. Bioanal. Chem. 400 (2011) 2641.

[20] K. Baghalian, S. Ziai, M. Naghavi, H. Badi, A. Khalighi, Evaluation of allicin content and botanical traits in Iranian garlic (Allium sativum L.) ecotypes, Sci. Hortic. 103 (2) (2005) 155-166.

[21] L. Díaz, K. Jiménez, Validación de un Método de Extracción de Alicina en Ajo y su Cuantificación por HPLC, Simposio de Metrólogia 1066 (2008) 1-9.

[22] O. Folin, V. Ciocalteu, On tyrosine and tryptophane determinations in proteins, J. Biol. Chem. 73 (1927) 627-650.

[23] P.J. Quinn, M.E. Carter, B. Markey, G.R. Carter, Clinical Veterinary Microbiology, second ed., Elsevier, Edinburgh, London, 2013.

[24] J. Bannoehr, L. Guardabassi, Staphylococcus pseudintermedius in the dog: taxonomy, diagnostics, ecology, epidemiology and pathogenicity, 23 (4) (2012) p 253-52.

[25] Noble, W.C., Staphylococci on the Skin in the Skin Microflora and Microbial Skin Disease 1992, Cambridge University Press: Cambridge. p. 135-152.

[26] W. Woraprayote, Y. Malila, S. Sorapukdee, A. Swetwiwathana, S. Benjakul, W. Visessanguan, Bacteriocins from lactic acid bacteria and their applications in meat and meat products, Meat Sci. 120 (2016) 118-132.

[27] V. Kavitha, A.B. Mandal, A. Gnanamani, Microbial biosurfactant mediated removal and/or solubilization of crude oil contamination from soil and aqueous phase: an approach with Bacillus licheniformis MTCC 5514, Int. Biodeterior. Biodegrad. 94
(2014) 24-30.

[28] E. Block, The organosulfur chemistry of the Genus Allium-Implications for the organic chemistry of sulfur, Angew. Chem. Int. Ed. 31 (1992) 1135-1178.

[29] O. Calvo-Gómez, J. Morales-López, M.G. López, Solid-phase microextraction-gas chromatographic-mass spectrometric analysis of garlic oil obtained by hydrodistillation, J. Chromatogr. 1036 (1) (2004) 91-93.

[30] C.A.L. Hincapié, G.E.P. López, R.C. Torres, Comparison and characterization of garlic (Allium sativum L.) bulbs extracts and their effect on mortality and repellency of Tetranychus urticae Koch (Acari: tetranychidae), Chil. J. Agric. Res. 68 (4) (2008) 317-327.

[31] D. Wang, Y. Feng, J. Liu, J. Yan, M. Wang, J.I. Sasaki, C. Lu, Black garlic (Allium sativum) extracts enhance the immune system, Med. Aromat. Plant Sci. Biotechnol. 4 (1) (2010) 37-40.

[32] E. Cáceres, F. Wilson, E.M. Ríos, lE Peñafie, C.C. Augusto, Determination of total phenols, fructans and pungency in six cultivars of garlic (Allium sativum L.) in Peru, J. Chem. Soc. Peru 76 (2010) 101-109.

[33] R. Padiya, D. Chowdhury, R. Borkar, R. Srinivas, B.M. Pal, S.K. Banerjee, Garlic attenuates cardiac oxidative stress via activation of PI3K/AKT/Nrf2-Keap1 pathway in fructose-fed diabetic rat, PloS One 9 (5) (2014) e94228.

[34] Z.Y. Al-Astal, Effect of storage and temperature of aqueous garlic extract on the growth of certain pathogenic bacteria, J. Al Azhar Univ. Gaza 6 (2003) 2-11.

[35] R.O. García Rico, F.C. Herrera Arias, Evaluation of the inhibition of the growth of five pathogenic bacterial strains by aqueous extracts of Allium sativum, Allium fistulosum and Allium cepa: preliminary study in vitro, Bistua: J. Facul. Basic Sci. 5 (2007) 68-79.

[36] L. Salazar Córdova, Antimicrobial Effect of Extracts of Allium Sativum L. "garlic" on the in vitro Growth of Escherichia coli ATCC 25922 and Staphylococcus aureus ATCC 25923, National University of Piura, 2014.

[37] S. Gorinstein, M. Leontowicz, H. Leontowicz, K. Najman, J. Namiesnik, Y.S. Park, S. Trakhtenberg, Supplementation of garlic lowers lipids and increases antioxidant capacity in plasma of rats, Nutr. Res. 26 (2006) 362-368.

[38] J.P.L. Pérez, Observation of the Antimicrobial Activity of Garlic (Allium Sativum) in the Secondary Education Laboratory in Eureka Magazine on Teaching and Dissemination of Sciences, (2011), pp. 491-494.

[39] S.E. Bae, S.Y. Cho, Y.D. Won, S.H. Lee, H.J. Park, A comparative study of the different analytical methods for analysis of S-allyl cysteine in black garlic by HPLC, LWT Food Sci. Technol. 46 (2012) 532-535.

[40] D.G. Kim, M.J. Kang, S.S. Hong, Y.H. Choi, J.H. Shin, Antiinflammatory effects of functionally active compounds isolated from aged black garlic, Phytother Res. 31 (1) (2017) 53-61.

[41] J.H. Ryu, D. Kang, Physicochemical properties, biological activity, health benefits, and general limitations of aged black garlic: a review, Molecules 22 (6) (2017) 919.

[42] E. Lydia, C. Gupta, A. Khusro, A.Z.M. Salem, Susceptibility of poultry associated bacterial pathogens to Momordica charantia fruits and evaluation of in vitro biological properties, Microb. Pathog. 132 (2019) 222-229.

[43] M.Z.M. Salem, M. EL-Hefny, H.M. Ali, H.O. Elansary, R.A. Nasser, A.A.A. El Settawy, N. El Shanhoery, N.A. Ashmawy, A.Z.M. Salem, Antibacterial activity of extracted bioactive molecules of Schinus terebinthifolius ripened fruits against some pathogenic bacteria, Microb. Pathog. 120 (2018) 119-127.

[44] M.Z.M. Salem, S.I. Behiry, A.Z.M. Salem, Effectiveness of root-bark extract from Salvadora persica against the growth of certain molecularly identified pathogenic bacteria, Microb. Pathog. 117 (2018) 320-326.

[45] A. Khusro, C. Aarti, A.Z.M. Salem, G.B. Rodríguez, R.R. Rivas-Cáceres, Antagonistic trait of Staphylococcus succinus strain AAS2 against uropathogens and assessment of its in vitro probiotic characteristics, Microb. Pathog. 118 (2018) 126-132.

[46] S.I. Behiry, A.A. Mohamed, H.A. Younes, M.Z.M. Salem, A.Z.M. Salem, Antigenic and pathogenicity activities of Ralstonia solanacearum race 3 biovar 2 molecularly identified and detected by indirect ELISA using polyclonal antibodies generated in rabbits, Microb. Pathog. 115 (2018) 216-221.

[47] A. Gutiérrez Morales, V. Velázquez Ordoñez, A. Khusro, A.Z.M. Salem, M.E. Estrada Zúñiga, M.Z.M. Salem, B. Valladares-Carranza, C. Burrola Aguilar, Anti-staphylococcal properties of Eichhornia crassipes, Pistacia vera, and Ziziphus amole leaf extracts: isolates from cattle and rabbits, Microb. Pathog. 113 (2017) 181-189.

[48] M.F. Echeverría Medina, P. Adeniyi Alaba, M.E. Estrada-Zuñiga, V. VelázquezOrdoñez, A. Barbabosa-Pliego, M.Z.M. Salem, M.U. Alonso-Fresán, L.M. CamachoDíaz, A.Z.M. Salem, Anti-staphylococcal properties of four plant extracts against sensitive and multi-resistant bacterial strains isolated from cattle and rabbits, Microb. Pathog. 113 (2017) 286-294.

[49] P. Vazquez-Mendoza, M.M.M. Elghandour, P. Adeniyi Alaba, P. Sánchez-Aparicio, M.U. Alonso-Fresán, A. Barbabosa-Pliego, A.Z.M. Salem, Antimicrobial and bactericidal impacts of Bacillus amyloliquefaciens CECT 5940 on fecal shedding of pathogenic bacteria in dairy calves and adult dogs, Microb. Pathog. 114 (2018) $458-463$.

[50] M. EL-Hefny, N.A. Ashmawy, M.Z.M. Salem, A.Z.M. Salem, Antibacterial activities of the phytochemicals-characterized extracts of Callistemon viminalis, Eucalyptus camaldulensis and Conyza dioscoridis against the growth of some phytopathogenic bacteria, Microb. Pathog. 113 (2017) 348-356.

[51] M.M.Y. Elghandour, A. Khusro, A.Z.M. Salem, M.A. Mariezcurrena-Berasain, L.M. Camacho Díaz, M. Cipriano-Salazar, Role of dose dependent Escherichia coli as ruminal anti-microflora agent to mitigate biogases production in prickly pear cactus flour based diet, Microb. Pathog. 115 (2018) 208-215.

[52] A.Z.M. Salem, A. Khusro, M.M.Y. Elghandour, J. Olivares-Pérez, S. RojasHernandez, R. Jiménez-Guillén, Susceptibility of ruminal bacteria isolated from large and small ruminant to multiple conventional antibiotics, Microb. Pathog. 121 (2018) 93-99.

[53] N.A. Ashmawy, M.Z.M. Salem, M. EL-Hefny, M.S.M. Abd El-Kareem, N.A. El- 
Shanhorey, A.A. Mohamed, A.Z.M. Salem, Antibacterial activity of the bioactive molecules identified in three woody plants against some pathogenic bacteria, Microb. Pathog. 121 (2018) 331-340.

[54] M.A. Mariezcurrena-Berasain, G. Velázquez-Garduño, P.M. Marín-Mendoza, A. Barbabosa Pliego, L.F.V. Castillo, B. Valladares Carranza, A. Khusro, E. Amadika Ugbogu, A.Z.M. Salem, Sensitivity of Coriandrum sativum extract on bacterial pathogens isolated from digestive system of rabbits, and its role on in vitro cecal gas production and fermentation, Microb. Pathog. 123 (2018) 18-23.

[55] M. Nosrati, F. Javandel, L.M. Camacho, A. Khusro, M. Cipriano, A. Seidavi, A.Z.M. Salem, The effects of antibiotic, probiotic, organic acid, vitamin C and Echinacea purpurea extract on performance, carcasses characteristics, blood chem istry, microbiota and immunity of broiler chickens, J. Appl. Poultry Res. 26 (2) (2017) 295-306.

[56] A. Hassan, S.H. Abu Hafsa, M.M.Y. Elghandour, P. Ravi Kanth Reddy, M.Z.M. Salem, U.Y. Anele, P.P. Ranga Reddy, A.Z.M. Salem, Influence of Corymbia citriodora leaf extract on growth performance, ruminal fermentation, nutrient digestibility, plasma antioxidant activity and faecal bacteria in young calves, Anim. Feed Sci. Technol. 261 (2020) 114394.

[57] A. Safaei-Cherehh, B. Rasouli, P. Adeniyi Alaba, A. Seidavi, S. Rojas Hernández, A.Z.M. Salem, Effect of dietary Foeniculum vulgare Mill. extract on growth performance, blood metabolites, immunity and ileal microflora in male broilers, Agrofor. Syst. (2020), https://doi.org/10.1007/s10457-018-0326-3 (in press).

[58] A. Parra-Garcia, M.M.Y. Elghandour, R. Greiner, A. Barbabosa-Pilego, L.M. Camacho-Diaz, A.Z.M. Salem, Effects of Moringa oleifera leaf extract on ruminal methane and carbon dioxide production and fermentation kinetics in a steer model,
Environ. Sci. Pollut. Control Ser. 26 (15) (2019) 15333-15344.

[59] M.M.Y. Elghandour, I. Rodríguez-Ocampo, A. Parra-Garcia, A.Z.M. Salem, R. Greiner, O. Marquez-Molina, M. Barros-Rodríguez, A. Barbabosa-Pilego, Biogas production from prickly pear cactus containing diets supplemented with Moringa oleifera leaf extract for a cleaner environmental livestock production, J. Clean. Prod. 185 (2018) 547-553.

[60] A. Parra-Garcia, A.Z.M. Salem, M.M.Y. Elghandour, L.M. Camacho, N. Odongo, Potential impact of prickly pear cactus flour and Salix babylonica extract on cecal fermentation and methane production in horses, Agrofor. Syst. 92 (2018) 1145-1154.

[61] M.M.Y. Elghandour, J.C. Cardenas-Chantres, A. Esquivel-Velázquez, A. BarbabosaPliego, M. Cipriano, A.Z.M. Salem, In vitro cecal gas and methane production of soybean hulls-containing diets in the presence of Salix babylonica extract as a fermentation modulator in horses, J. Equine Vet. Sci. 53 (2017) 45-54.

[62] J. Pedraza-Hernández, M.M.Y. Elghandour, A. Khusro, L.M. Camacho, L.H. Vallejo, A. Barbabosa-Pliego, A.Z.M. Salem, Mitigation of ruminal biogases production from goats using Moringa oleifera extract and live yeast culture for a cleaner agriculture environment, J. Clean. Prod. 234 (2019) 779-786.

[63] M.J. Adegbeye, M.M.Y. Elghandour, J.C. Monroy, T.O. Abegunde, A.Z.M. Salem, A. Barbabosa-Pliego, T.O. Faniyi, Potential influence of Yucca extract as feed additive on greenhouse gases emission for a cleaner livestock and aquaculture farming - a review, J. Clean. Prod. 239 (2019) 118074.

[64] M. Zeineldin, R. Barakat, A. Elolimy, A.Z.M. Salem, M.M.Y. Elghandour, J.C. Monroy, Synergetic action between the rumen microbiota and bovine health, Microb. Pathog. 124 (2018) 106-115. 